\title{
Novel k-opioid receptor agonist MB-1C-OH produces potent analgesia with less depression and sedation
}

\author{
Le-sha ZHANG ${ }^{1}$, Jun WANG ${ }^{1,2}$, Jian-chun $\mathrm{CHEN}^{3}$, Yi-min $\mathrm{TAO}^{1}$, Yu-hua $W A N G^{2,4}$, Xue-jun $X \mathrm{U}^{1}$, Jie $\mathrm{CHEN}^{1}$, Yun-gen $X \mathrm{U}^{2}$, \\ Tao $\mathrm{XI}^{2}$, Xiao-wu $\mathrm{HU}^{3, *}$, Yu-jun WANG ${ }^{1, *}$, Jing-gen LIU $^{1}$ \\ ${ }^{1}$ State Key Laboratory of Drug Research, Shanghai Institute of Materia Medica and Collaborative Innovation Center for Brain Science, \\ Chinese Academy of Sciences, Shanghai 201203, China; ${ }^{2}$ Biotechnology Center, School of Life Science and Technology, China \\ Pharmaceutical University, Nanjing 210009, China; ${ }^{3}$ Department of Neurosurgery, Changhai Hospital, Second Military Medical \\ University, Shanghai 200433, China; ${ }^{4}$ School of Pharmacy, Nanjing University of Chinese Medicine, Nanjing 210046, China
}

\begin{abstract}
Aim: To characterize the pharmacological profiles of a novel k-opioid receptor agonist $\mathrm{MB}-1 \mathrm{C}-\mathrm{OH}$.
Methods: $\left[{ }^{3} \mathrm{H}\right]$ diprenorphine binding and $\left[{ }^{35} \mathrm{~S}\right] \mathrm{GTP} Y \mathrm{~S}$ binding assays were performed to determine the agonistic properties of MB-1C-OH. Hot plate, tail flick, acetic acid-induced writhing, and formalin tests were conducted in mice to evaluate the antinociceptive actions. Forced swimming and rotarod tests of mice were used to assess the sedation and depression actions.

Results: In $\left[{ }^{3} \mathrm{H}\right]$ diprenorphine binding assay, MB-1C-OH did not bind to $\mu$ - and $\delta$-opioid receptors at the concentration of $100 \mu$ mol/L, but showed a high affinity for K-opioid receptor $\left(K_{\mathrm{i}}=35 \mathrm{nmol} / \mathrm{L}\right)$. In $\left[{ }^{35} \mathrm{~S}\right] \mathrm{GTPyS}$ binding assay, the compound had an $E_{\max }$ of $98 \%$ and an $\mathrm{EC}_{50}$ of $16.7 \mathrm{nmol} / \mathrm{L}$ for k-opioid receptor. Subcutaneous injection of MB-1C-OH had no effects in both hot plate and tail flick tests, but produced potent antinociception in the acetic acid-induced writhing test $\left(\mathrm{ED}_{50}=0.39 \mathrm{mg} / \mathrm{kg}\right)$, which was antagonized by pretreatment with a selective K-opioid receptor antagonist Nor-BNI. In the formalin test, subcutaneous injection of MB-1C-OH did not affect the flinching behavior in the first phase, but significantly inhibited that in the second phase $\left(E D_{50}=0.87 \mathrm{mg} / \mathrm{kg}\right)$. In addition, the sedation or depression actions of MB-1C-OH were about 3-fold weaker than those of the classical $\mathrm{K}$ agonist $(-) \mathrm{U} 50,488 \mathrm{H}$.

Conclusion: $\mathrm{MB}-1 \mathrm{C}-\mathrm{OH}$ is a novel $\mathrm{k}-\mathrm{opioid}$ receptor agonist that produces potent antinociception causing less sedation and depression.
\end{abstract}

Keywords: K-opioid receptor; MB-1C-OH; (-)U50,488H; Nor-BNI; morphine; pain; acetic acid-induced writhing; formalin test; depression; sedation

Acta Pharmacologica Sinica (2015) 36: 565-571; doi: 10.1038/aps.2014.145; published online 30 Mar 2015

\section{Introduction}

Opioid receptors have been classified into $\mu-, \kappa_{-}$, and $\delta$-opioid receptors based on their different pharmacological profiles ${ }^{[1]}$. Currently, most opioid analgesics, such as morphine, mainly induce analgesia via binding to the $\mu$-opioid receptor, but they are also associated with a spectrum of undesirable side effects, such as physical dependence, respiratory depression, and constipation ${ }^{[2]}$. Numerous studies have demonstrated that drugs targeting $\mathrm{K}$-opioid receptor produced potent antinociception with less adverse and fewer addictive side effects than $\mu$-opioid receptor agonists ${ }^{[3-5]}$. Endoh et al reported that TRK-820, a K-opioid receptor agonist, was 68- to 328-fold more potent than (-)U50,488H, and 41- to 349 -fold more potent than

\footnotetext{
* To whom correspondence should be addressed.

E-mail yjwang@mail.simm.ac.cn (Yu-jun WANG); huxiaowu25@sina.com (Xiao-wu HU)

Received 2014-08-09 Accepted 2014-11-10
}

morphine in producing antinociception ${ }^{[6]}$. We previously found that LPK-26 produced potent antinociceptive effects without inducing physical dependence ${ }^{[7]}$. However, selective K-opioid agonists frequently exhibit severe central nervous system side effects such as sedation and depression, which limit their clinical use ${ }^{[8]}$.

Increasing evidence from a wide variety of visceral pain models, inflammatory pain models and thermal hyperalgesia induced by capsaicin show that $\mathrm{k}$-opioid agonists could produce their analgesic effects via peripheral targeting ${ }^{[9-13]}$. Thus, peripherally acting $\mathrm{\kappa}$-opioid agonists may be more promising candidate pharmacotherapies for pain relief because they do not cause central nervous system side effects.

In this study, a novel synthetic compound, $\mathrm{MB}-1 \mathrm{C}-\mathrm{OH}$ (empirical formula: $\mathrm{C}_{24} \mathrm{H}_{25} \mathrm{ClN}_{2} \mathrm{O}_{3}$, molecular weight: 424), in which a hydroxyl group was introduced in the parent framework of MB-1C, was examined (Figure 1). MB-1C-OH was characterized using in vitro and in vivo experiments. Specifi- 
cally, MB-1C-OH's binding affinity for opioid receptors $(\mu$, $\mathrm{K}$, and $\delta)$ and ability to stimulate guanosine5'-O-(3-[ $\left.{ }^{35} \mathrm{~S}\right]$ thio) triphosphate $\left.\left({ }^{35} \mathrm{~S}\right] \mathrm{GTP} \gamma \mathrm{S}\right)$ binding to G-proteins were determined. The antinociceptive effects of MB-1C-OH were evaluated in the hot plate, tail flick, acetic acid-induced writhing and formalin tests.
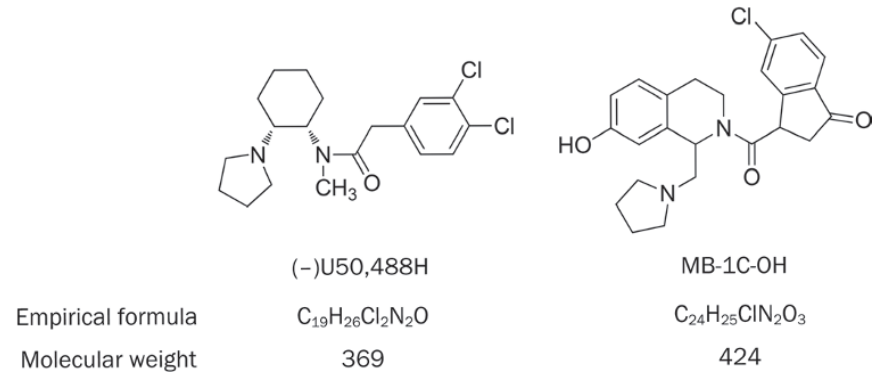

Figure 1. Chemical structures of (-)U50,488H and MB-1C-OH.

\section{Materials and methods Cell culture}

Chinese hamster ovary $(\mathrm{CHO})$ cells were transfected with human $\mathrm{K}-$, rat $\mu$-, or rat $\delta$-opioid receptors using Lipofectamine (Invitrogen) as per the manufacturer's protocol. CHO cells stably expressing human $\mathrm{k}-$, rat $\mu$-, or rat $\delta$-opioid receptors were maintained in F12 medium (Gibco) with 10\% fetal calf serum and $0.25 \mathrm{mg} / \mathrm{mL}$ G418 (Roche). Cells were incubated in a humidified atmosphere consisting of $5 \% \mathrm{CO}_{2}, 95 \%$ air at $37^{\circ} \mathrm{C}$. For the receptor binding assay and the $\left[{ }^{35} \mathrm{~S}\right] \mathrm{GTP} \gamma \mathrm{S}$ binding assay, cells were seeded into $175-\mathrm{cm}^{3}$ flasks. When cell growth reached $70 \%$ confluence, cells were washed with phosphatebuffered saline and the membrane was prepared as follows.

\section{Cell membrane preparation}

$\mathrm{CHO}$ cells were detached by incubation with phosphatebuffered saline containing $1 \mathrm{mmol} / \mathrm{L}$ EDTA and centrifuged at $1000 \times g$ for $10 \mathrm{~min}$. The cell pellet was suspended in icecold homogenization buffer composed of $50 \mathrm{mmol} / \mathrm{L}$ HEPES, $\mathrm{pH}$ 7.4; $1 \mathrm{mmol} / \mathrm{L} \mathrm{MgCl}_{2}$; and $1 \mathrm{mmol} / \mathrm{L}$ EGTA. Cells were homogenized with 10 strokes using a glass Dounce homogenizer. After centrifugation at $40000 \times g$ for $10 \mathrm{~min}\left(4^{\circ} \mathrm{C}\right)$, pellets were resuspended in homogenization buffer, homogenized, and centrifuged again as described. This procedure was repeated twice more. The final pellets were resuspended in 50 $\mathrm{mmol} / \mathrm{L}$ Tris- $\mathrm{HCl}$ buffer, $\mathrm{pH}$ 7.4. The protein concentration was determined, and aliquots were stored at $-80^{\circ} \mathrm{C}$.

\section{Receptor binding assay}

Ligand binding experiments were performed with $\left[{ }^{3} \mathrm{H}\right]$ diprenorphine for opioid receptors. Competition inhibition of $\left[{ }^{3} \mathrm{H}\right]$ diprenorphine binding to opioid receptors by MB-1C-OH or (-) U50,488H was performed in the absence or presence at various concentration of each drug. The receptor binding assay was carried out in triplicate using $50 \mathrm{mmol} / \mathrm{L}$ Tris-
$\mathrm{HCl}$ buffer ( $\mathrm{pH} \mathrm{7.4)}$ at $37^{\circ} \mathrm{C}$ for $30 \mathrm{~min}$ in a final volume of 0.5 $\mathrm{mL}$ with $30 \mu \mathrm{g}$ of membrane protein. Naloxone $(10 \mu \mathrm{mol} / \mathrm{L}$, Sigma) was used to define nonspecific binding. Bound and free $\left[{ }^{3} \mathrm{H}\right]$ diprenorphine were separated by filtration under reduced pressure with GF/B filters (Whatman). The amount of radioactivity on the filters was determined using a liquid scintillation counter (Beckman LS6500).

\section{GTPyS binding assay}

$\left[{ }^{35} \mathrm{~S}\right] \mathrm{GTP} \gamma \mathrm{S}$ binding was performed as described previously ${ }^{[14,15]}$. Briefly, membranes ( $15 \mu \mathrm{g} /$ sample) were incubated with $0.1 \mathrm{nmol} / \mathrm{L}\left[{ }^{35} \mathrm{~S}\right] \mathrm{GTP} \gamma \mathrm{S}$ in a binding buffer composed of $50 \mathrm{mmol} / \mathrm{L}$ Tris- $\mathrm{HCl}, \mathrm{pH}$ 7.5; $1 \mathrm{mmol} / \mathrm{L}$ EDTA; $5 \mathrm{mmol} / \mathrm{L}$ $\mathrm{MgCl}_{2} ; 100 \mathrm{mmol} / \mathrm{L} \mathrm{NaCl}$; and $40 \mu \mathrm{mol} / \mathrm{L} \mathrm{GDP}$ at $30^{\circ} \mathrm{C}$ for $1 \mathrm{~h}$ in the presence of increasing concentrations of MB-1C-OH. Nonspecific binding was determined in the presence of nonradioactive GTPYS $(10 \mu \mathrm{mol} / \mathrm{L})$. Reactions were terminated by rapid filtration, and the amount of bound radioactivity was determined by liquid scintillation counting as described above. The percentage of stimulated $\left[{ }^{35} \mathrm{~S}\right] \mathrm{GTP} \gamma \mathrm{S}$ binding was calculated as $100 \times\left(\mathrm{cpm}_{\text {sample }}-\mathrm{cpm}_{\text {nonspecific }}\right) /\left(\mathrm{cpm}_{\text {basal }}-\mathrm{cpm}_{\text {nonspecific }}\right)$.

\section{Animals}

Male Kunming strain mice (approximately $20 \mathrm{~g}$ ) were obtained from the Laboratory Animal Center, Chinese Academy of Sciences (Shanghai, China). Mice were housed in groups and maintained in a 12/12 h light/dark cycle in a temperature controlled environment with free access to food and water. Ten to fifteen mice were used per treatment group. All animal treatments were strictly in accordance with the institutional guidelines of Animal Care and Use Committee, Shanghai Institute of Materia Medica, Chinese Academy of Sciences.

\section{Hot plate test}

The hot plate test was performed according to the method we described previously ${ }^{[4,16]}$. Briefly, the hot plate temperature was set at $55^{\circ} \mathrm{C}$. Mice were placed on the heated smooth surface. The amount of time that elapsed before the mice showed the first signs of discomfort (hind-paw lifting, licking or shaking, and jumping) was recorded. Prior to drug administration, the nociceptive response for each mouse was measured two times. The mean of these two times was used as the basal response time for each mouse. A cut-off time of $60 \mathrm{~s}$ was used in the test to avoid tissue damage. Each test was undertaken $15 \mathrm{~min}$ after the drug was administered. The Maximum Possible Effect (\% MPE) was calculated as: 100×(response time after drug treatment - basal response time before drug treatment)/ (cut-off time - basal latency before response time without drug treatment).

\section{Acetic acid-induced writhing test}

The acetic acid-induced writhing test was performed in mice according to our previously reported procedure ${ }^{[4,16]}$. Abdominal constriction was induced by the injection of $0.6 \%$ acetic acid $(10 \mathrm{~mL} / \mathrm{kg}, \mathrm{ip})$. An abdominal constriction was defined as a wave of contraction of the abdominal musculature fol- 
lowed by extension of the hind limbs. Acetic acid solution was injected ip 15 min after the administration of the drug, and the number of abdominal constrictions was counted for $15 \mathrm{~min}$ after acetic acid administration. The Maximum Possible Effect (\% MPE) was calculated as: $100 \times($ mean abdominal constriction in vehicle treated group - constriction times in drug-treated animal)/mean abdominal constriction in vehicle treated group. In all experiments with mice, drugs were given by a subcutaneous (sc) route prior to acetic acid administration. To determine the in vivo agonist profile of $\mathrm{MB}-1 \mathrm{C}-\mathrm{OH}$, mice were pretreated with a $\mathrm{K}$-(or-binaltorphimine (Nor-BNI), $10 \mathrm{mg} / \mathrm{kg}$, sc, $-15 \mathrm{~min})^{[7,16,17]}, \mu$ - $(\beta$-funaltrexamine $(\beta$-FNA $), 10 \mathrm{mg} / \mathrm{kg}$, sc, $-24 \mathrm{~h})^{[18,19]}$ or $\delta$-(naltrindole, $\left.3.0 \mathrm{mg} / \mathrm{kg}, \mathrm{sc},-30 \mathrm{~min}\right)^{[20]}$ opioid receptor antagonist before $\mathrm{MB}-1 \mathrm{C}-\mathrm{OH}$ administration.

\section{Tail flick test}

The tail-flick assay was performed according to our previously reported procedure ${ }^{[4,16]}$. Briefly, a beam of light was focused on the dorsal surface of the tail approximately $1-2 \mathrm{~cm}$ from the tip, and the amount of time that it took the mouse to withdraw its tail from the noxious stimulus was recorded. Before drug administration, the nociceptive response of each mouse was measured twice with a between trial interval of $5 \mathrm{~min}$, and the mean of the two trials was recorded as the basal response time without drug treatment. Mice that did not have a basal response time between 2 and $7 \mathrm{~s}$ were excluded from further studies. A cut-off time of $14 \mathrm{~s}$ was employed as the maximum possible duration in the test after drug treatment in order to prevent tissue damage. The test was conducted 15 min after the administration of the drug. The Maximum Possible Effect (\% MPE) was calculated as follows: $100 \times$ (response time after drug treatment - basal response time before drug treatment)/ (cut-off time - basal latency before drug treatment).

\section{Formalin test}

The formalin test was performed according to the method described previously ${ }^{[21]}$. Briefly, $20 \mu \mathrm{L}$ of $1.0 \%$ formalin was injected to the plantar surface of the right hind paw. The mice were observed for $60 \mathrm{~min}$ after the injection of formalin, and the amount of time that the mice spent licking or flinching the injected hind paw was recorded. The first $10 \mathrm{~min}$ after an injection of formalin was recorded as the early phase, and the period between $10 \mathrm{~min}$ and $60 \mathrm{~min}$ was recorded as the late phase. The drugs were administered 15 min before the injection of formalin. The total time that the mice spent licking or flinching the injured paw (pain behavior) was measured with a stopwatch.

\section{Forced swimming test (FST)}

The forced swimming test was performed according to the method described previously ${ }^{[22]}$. Mice were put singly into transparent Plexiglas cylinders (height: $24 \mathrm{~cm}$, diameter: $13 \mathrm{~cm}$ ) containing water at a depth of $10 \mathrm{~cm}$, maintained at $22^{\circ} \mathrm{C}$ for $6 \mathrm{~min}$. The amount of time that the mice remained immobile was recorded in seconds during the final $4 \mathrm{~min}$ of the test. The percentage of depression was calculated as: $100 \times\left(\right.$ immobility time) $/ 240$, and then, the $\mathrm{ED}_{50}$ value was calculated using software which was based on the Litchfield and Wilcoxon method ${ }^{[23]}$.

\section{Rotarod test}

The rotarod test was conducted using a procedure described previously ${ }^{[16,24]}$. The maximum time tested was prolonged from $60 \mathrm{~s}$ to $300 \mathrm{~s}$. In brief, the machine was set at a fixed rotational rate of 8 rounds per minute. The animals were trained twice a day for three consecutive days to maintain their position for $300 \mathrm{~s}$ without falling off the rotarod. The formal test began 15 min after the administration of the drug. The duration time for each mouse to remain on the Rotarod was recorded in seconds. The percentage of sedation was calculated as $100 \times(300$ - duration time after test drug treatment)/300 and was used to determine the $\mathrm{ED}_{50}$ values of the test drugs.

\section{Drugs}

$\left[{ }^{3} \mathrm{H}\right]$ diprenorphine $(1.85 \mathrm{TBq} / \mathrm{mmol})$ and guanosine 5-O-(3$\left[{ }^{35} \mathrm{~S}\right]$ thio)triphosphate $\left(\left[{ }^{35} \mathrm{~S}\right] \mathrm{GTP} \gamma \mathrm{S}\right)(38.11 \mathrm{TBq} / \mathrm{mmol})$ were purchased from Amersham Biosciences (Piscataway, NJ, USA). (-)U50,488H; naloxone; naltrindole; nor-binaltorphimine; $\beta$-funaltrexamine; GTP $\gamma$ S and GDP were obtained from Sigma-Aldrich (St Louis, MO, USA). Morphine hydrochloride was purchased from Qinghai Pharmaceutical General Factory (Xining, China).

\section{Statistical analysis}

Curve-fitting analyses were performed using GraphPad Prism 4.02 software. Results are expressed as the mean \pm SEM of at least three separate experiments. Statistical significance was determined using ANOVA (one- or two-way) followed by post hoc comparison using Dunnett's tests. When only two groups were compared, statistical significance was determined using unpaired Student's $t$-tests.

\section{Results}

\section{Affinity, selectivity, and efficacy of MB-1C-OH}

Competitive inhibition of $\left[{ }^{3} \mathrm{H}\right]$ diprenorphine binding to opioid receptors by $\mathrm{MB}-1 \mathrm{C}-\mathrm{OH}$ was performed to examine the binding affinities of $\mathrm{MB}-1 \mathrm{C}-\mathrm{OH}$ to the opioid receptors $(\mu, \mathrm{k}$, and $\delta)$. The $K_{\mathrm{i}}$ of $\mathrm{MB}-1 \mathrm{C}-\mathrm{OH}$ was $35 \mathrm{nmol} / \mathrm{L}$ to inhibit the binding of $\left[{ }^{3} \mathrm{H}\right]$ diprenorphine to the $\mathrm{\kappa}$-opioid receptor, whereas MB-1C-OH at concentrations as high as $100 \mu \mathrm{mol} / \mathrm{L}$ showed no affinity for the $\mu$ - or $\delta$-opioid receptors (Table 1$)$. In the $\left[{ }^{35} \mathrm{~S}\right] \mathrm{GTP} Y \mathrm{~S}$ binding assay, MB-1C-OH had an $E_{\max }$ (percentage of maximal stimulation) of $98.19 \%$ for the $\mathrm{K}$-opioid receptor. The $\mathrm{EC}_{50}$ of MB-1C-OH to stimulate $\left[{ }^{35} \mathrm{~S}\right] \mathrm{GTP \gamma S}$ binding to the K-opioid receptor was $16.7 \mathrm{nmol} / \mathrm{L}$ (Table 1).

\section{Antinociceptive effects of $\mathrm{MB}-1 \mathrm{C}-\mathrm{OH}$ were mediated by the k-opioid receptor}

As shown in Table 2, in the hot plate and tail flick tests, MB$1 \mathrm{C}-\mathrm{OH}$ had no significant antinociceptive effects. $\mathrm{MB}-1 \mathrm{C}-\mathrm{OH}$ $(10 \mathrm{mg} / \mathrm{kg}, \mathrm{sc})$ did not produce significant analgesic effects in 
both mouse hot plate and tail flick tests, which was similar to the data that we got from dose of $6 \mathrm{mg} / \mathrm{kg}$ (data not shown). Morphine and (-) U50,488H produced antinociception in the hot plate test with $\mathrm{ED}_{50}$ values of 6.95 and $4.42 \mathrm{mg} / \mathrm{kg}$, respectively, and in the tail flick test with $\mathrm{ED}_{50}$ values of 3.46 and 5.02 $\mathrm{mg} / \mathrm{kg}$, respectively.

In the mouse acetic acid-induced writhing test, MB-1C-OH produced significant antinociception with an $\mathrm{ED}_{50}$ value of $0.39 \mathrm{mg} / \mathrm{kg}$, which was approximately 2.3-fold smaller than the $\mathrm{ED}_{50}$ for (-) $\mathrm{U} 50,488 \mathrm{H}(0.89 \mathrm{mg} / \mathrm{kg})$, and 2.1-fold smaller than the $\mathrm{ED}_{50}$ for morphine $(0.84 \mathrm{mg} / \mathrm{kg})$ (Table 2$)$. The antinociceptive effect of $\mathrm{MB}-1 \mathrm{C}-\mathrm{OH}$ in the acetic acid-induced writhing test was also completely antagonized by the $\mathrm{k}$-opioid receptor antagonist nor-BNI but not by the $\mu$ - or $\delta$-opioid receptor antagonists (Figure 2). One-way ANOVA tests $\left(F_{3,36}=22.34, P<0.01\right)$ and the following post hoc comparison using Dunnett's tests $(P<0.01)$ revealed a significant effect of the ability of nor-BNI to inhibit the antinociceptive effect of $\mathrm{MB}-1 \mathrm{C}-\mathrm{OH}$. These results suggested that the $\mathrm{K}$-opioid receptor is involved in MB-1C-OH-mediated antinociceptive effects.

In the formalin test, MB-1C-OH dose-dependently inhibited formalin-induced pain only in the second phase with an $\mathrm{ED}_{50}$ of $0.87 \mathrm{mg} / \mathrm{kg}$ (Figure 3, Table 3), which was similar to the pattern of antinociception produced by (-) U50,488H but different from the antinociception produced by morphine. In Figure 3, one-way ANOVA tests $\left(F_{4,45}=22.53, P<0.01\right)$ and the following post hoc comparison using Dunnett's tests revealed that doses of $1.25 \mathrm{mg} / \mathrm{kg}(P<0.01), 2.5 \mathrm{mg} / \mathrm{kg}(P<0.01)$ and
$6.25 \mathrm{mg} / \mathrm{kg}(P<0.01)$ of MB-1C-OH could significantly inhibit formalin-induced pain in second phase. As shown in Table 3, (-) U50,488H produced antinociception on the second phase with an $\mathrm{ED}_{50}$ of $0.41 \mathrm{mg} / \mathrm{kg}$. Morphine acted on both phases with $\mathrm{ED}_{50}$ values of $5.05 \mathrm{mg} / \mathrm{kg}$ in the first phase and 3.06 $\mathrm{mg} / \mathrm{kg}$ in the second phase.

\section{Depressive side effect of $\mathrm{MB}-1 \mathrm{C}-\mathrm{OH}$ in the forced swimming test} $\mathrm{MB}-1 \mathrm{C}-\mathrm{OH}$ and (-) $\mathrm{U} 50,488 \mathrm{H}$ dose-dependently increased the immobility time during the forced swimming test (Figure 4A). As shown in Table 4, the depressive $\mathrm{ED}_{50}$ of $\mathrm{MB}-1 \mathrm{C}-\mathrm{OH}$ in the FST was $9.49 \mathrm{mg} / \mathrm{kg}$, which was 4 times higher than that of (-) $\mathrm{U} 50,488 \mathrm{H}(2.35 \mathrm{mg} / \mathrm{kg})$. The ratio of the depressive $\mathrm{ED}_{50}$ to the antinociceptive $\mathrm{ED}_{50}$ of $\mathrm{MB}-1 \mathrm{C}-\mathrm{OH}$ was 24.33 , which was 9.2 times higher than that of (-) $\mathrm{U} 50,488 \mathrm{H}$ (2.64), suggesting that $\mathrm{MB}-1 \mathrm{C}-\mathrm{OH}$ has a lower potential to cause depression than the classical K-opioid agonist (-) $\mathrm{U} 50,488 \mathrm{H}$.

\section{Sedative side effect of MB-1C-OH in the rotarod test}

K-Opioid agonists often produce the undesirable side effect of sedation in therapeutic use. MB-1C-OH also caused a dosedependent inhibition in rotarod performance (Figure 4B). As shown in Table 4, the sedative $\mathrm{ED}_{50}$ values of $\mathrm{MB}-1 \mathrm{C}-\mathrm{OH}$ and (-)U50,488H were $9.29 \mathrm{mg} / \mathrm{kg}$ and $3.32 \mathrm{mg} / \mathrm{kg}$, respectively. The ratio of the sedative $\mathrm{ED}_{50}$ to the antinociceptive $\mathrm{ED}_{50}$ of MB-1C-OH was 23.82, which was 6.4 times higher than that of (-) $\mathrm{U} 50,488 \mathrm{H}$ (3.73), suggesting that $\mathrm{MB}-1 \mathrm{C}-\mathrm{OH}$ has a lower risk for causing sedation than (-) $\mathrm{U} 50,488 \mathrm{H}$.

Table 1. Affinity values $\left(K_{i}\right)$ for the binding to opioid receptors and $\mathrm{EC}_{50}$ values as well as maximal effects in stimulating $\left[{ }^{35} \mathrm{~S}\right] \mathrm{GTP} S \mathrm{~S}$ binding to membranes of $\mathrm{MB}-1 \mathrm{C}-\mathrm{OH}$ and $(-) \mathrm{U} 50,488 \mathrm{H}$ in $\mathrm{CHO}$ cells stably expressing opioid receptors.

\begin{tabular}{|c|c|c|c|c|c|}
\hline \multirow{2}{*}{ Compounds } & \multirow{2}{*}{$\begin{array}{c}{\left[{ }^{3} \mathrm{H}\right] \text { diprenorphine }} \\
(\mu)\end{array}$} & \multirow{2}{*}{$\begin{array}{l}\text { Receptor binding } K_{\mathrm{i}}(\mathrm{nmol} / \mathrm{L}) \\
{\left[{ }^{3} \mathrm{H}\right] \text { diprenorphine }} \\
\text { (к) }\end{array}$} & \multirow{2}{*}{$\begin{array}{c}{\left[{ }^{3} \mathrm{H}\right] \text { diprenorphine }} \\
(\delta)\end{array}$} & \multicolumn{2}{|c|}{$\begin{array}{c}{\left[{ }^{35} \mathrm{~S}\right] \mathrm{GTP \gamma S} \text { binding assay }} \\
\mathrm{K}\end{array}$} \\
\hline & & & & $E_{\max }$ & $\mathrm{EC}_{50}(\mathrm{nmol} / \mathrm{L})$ \\
\hline $\mathrm{MB}-1 \mathrm{C}-\mathrm{OH}$ & N.B & $35.13 \pm 1.74$ & N.B & $98.19 \%$ & $16.70 \pm 0.32$ \\
\hline$(-) \cup 50,488 \mathrm{H}^{\mathrm{a}}$ & $1397.00 \pm 488.00$ & $6.08 \pm 0.10$ & N.B & $100 \%$ & $3.75 \pm 0.31$ \\
\hline
\end{tabular}

${ }^{a}$ The data of (-) U50,488H were cited from our precious data ${ }^{[7]}$.

Membranes stably expressing opioid receptors in Chinese hamster ovary cells were incubated with varying concentrations of $\mathrm{MB}-1 \mathrm{C}-\mathrm{OH}$ and $(-) \mathrm{U} 50,488 \mathrm{H}$ in the presence of $\left[{ }^{3} \mathrm{H}\right]$ diprenorphine $(1 \mathrm{nmol} / \mathrm{L})$, or $\left[{ }^{35} \mathrm{~S}\right] \mathrm{GTPYS}(0.1 \mathrm{nmol} / \mathrm{L})$ as described in Materials and methods. Data were derived from the curves in Figure 2 and 3. Data were presented as the mean \pm SEM for at least three independent experiments preformed in triplicate. N.B did not bind at $100 \mu \mathrm{mol} / \mathrm{L}$.

Table 2. $\mathrm{ED}_{50}$ values of the maximal possible effect (\% MPE) produced by MB-1C-OH, morphine, and (-) U50,488H evaluated with hot plate, tail flick and acetic acid-induced writhing tests.

\begin{tabular}{lccc}
\hline Compounds & $\begin{array}{c}\text { Hot plate test } \\
(\mathrm{mg} / \mathrm{kg}, \mathrm{sc})\end{array}$ & $\begin{array}{c}\text { Tail flick test } \\
(\mathrm{mg} / \mathrm{kg}, \mathrm{sc})\end{array}$ & $\begin{array}{c}\text { Acetic acid-induced writhing test } \\
(\mathrm{mg} / \mathrm{kg}, \mathrm{sc})\end{array}$ \\
\hline MB-1C-OH & - & - & $0.39(0.24-0.66)$ \\
Morphine & $6.95(5.68-8.50)^{\mathrm{a}}$ & $3.46(3.21-3.72)$ & $0.84(0.56-1.27)^{\mathrm{a}}$ \\
$(-) \mathrm{U} 50,488 \mathrm{H}$ & $4.42(2.51-7.75)^{\mathrm{a}}$ & $5.02(4.58-5.51)$ & $0.89(0.54-1.44)^{\mathrm{a}}$ \\
\hline
\end{tabular}

${ }^{a}$ The data of $(-) \cup 50,488 \mathrm{H}$ and morphine associated with hot plate and acetic acid-induced writhing tests were cited from our precious data ${ }^{[7]}$. The data was obtained at $15 \mathrm{~min}$ after drug administration (in parentheses are 95\% confidence limits). 


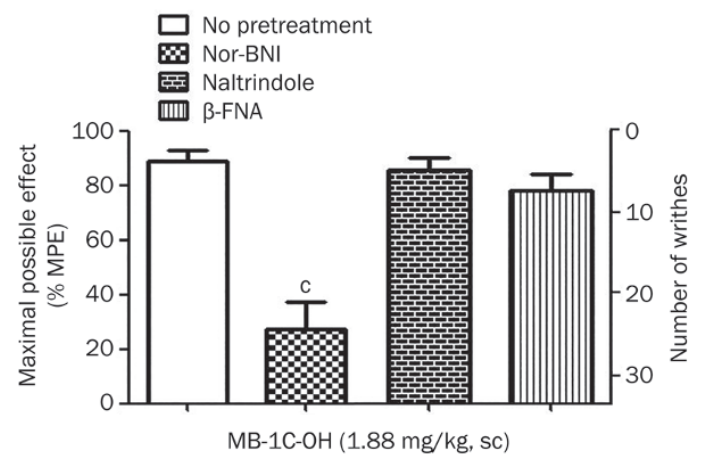

Figure 2. Effects of pretreatment with Nor-BNI, $\beta-F N A$, and naltrindole on $\mathrm{MB}-1 \mathrm{C}-\mathrm{OH}$-induced antinociception in the acetic acid-induced writhing assay. Mice were pretreated with the $\mu$-opioid receptor antagonist, $\beta$-FNA (10 mg/kg, sc) $24 \mathrm{~h}$ before MB-1C-OH administration; the $\delta$-opioid receptor antagonist, naltrindole $(3.0 \mathrm{mg} / \mathrm{kg}, \mathrm{sc}) 30 \mathrm{~min}$ before $\mathrm{MB}-1 \mathrm{C}-\mathrm{OH}$ administration; or the selective k-opioid receptor antagonist, Nor-BNI (10 $\mathrm{mg} / \mathrm{kg}$, sc) $15 \mathrm{~min}$ before MB-1C-OH administration and then injected with MB-1C-OH $(1.88 \mathrm{mg} / \mathrm{kg}, \mathrm{sc})$. Acetic acid solution was intraperitoneally injected $15 \mathrm{~min}$ after drug administration. The maximum possible effect (\% MPE) was calculated as described in the Materials and methods section, and the number of times the mouse writhed is also shown. Data are presented as the mean \pm SEM from 10 animals. ${ }^{c} P<0.01$ compared with the control group.

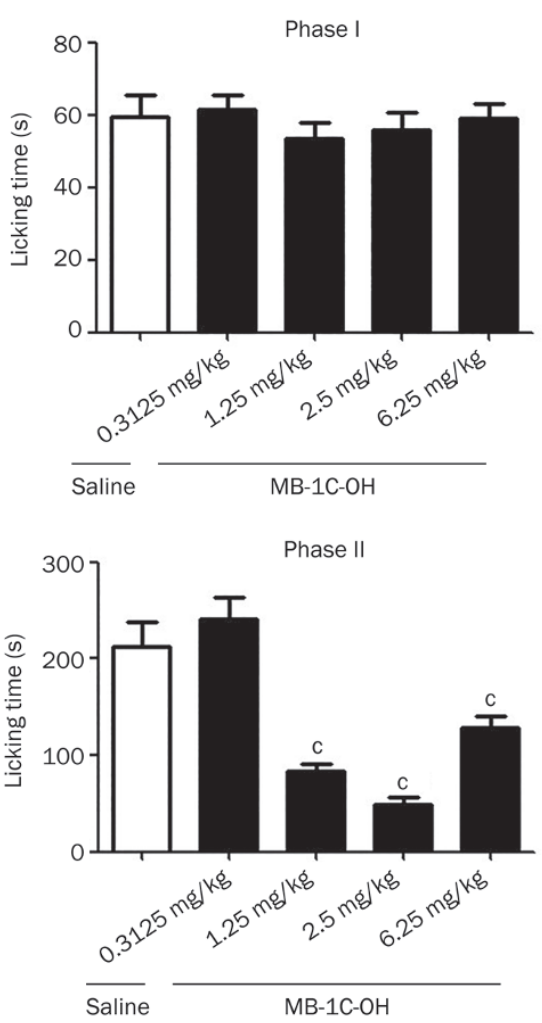

Figure 3. $\mathrm{MB}-1 \mathrm{C}-\mathrm{OH}$-induced antinociceptive effects in the formalin test. The animals were pretreated with $\mathrm{MB}-1 \mathrm{C}-\mathrm{OH}$ into subcutaneous. After 15 min, the animals were injected with formalin $(20 \mu \mathrm{L} /$ paw $)$. The amount of time the mice spent licking or flinching during first phase and second phase was recorded. All data are expressed as the mean \pm SEM (at least five animals in each group). ${ }^{c} P<0.01$ compared with the vehicle group (one-way ANOVA with Dunnett's test).
Table 3. $\mathrm{ED}_{50}$ of each drug maximal possible effect (\% MPE) measured by the formalin test in mice.

\begin{tabular}{lcc}
\hline Compounds & \multicolumn{2}{c}{$\begin{array}{c}\text { Antinociceptive } \mathrm{ED}_{50}(\mathrm{mg} / \mathrm{kg}, \mathrm{sc}) \\
\text { Phase I }\end{array}$} \\
\hline Phase II
\end{tabular}

The data was calculated obtained at 15 min after drug administration (in parentheses are 95\% confidence limits).
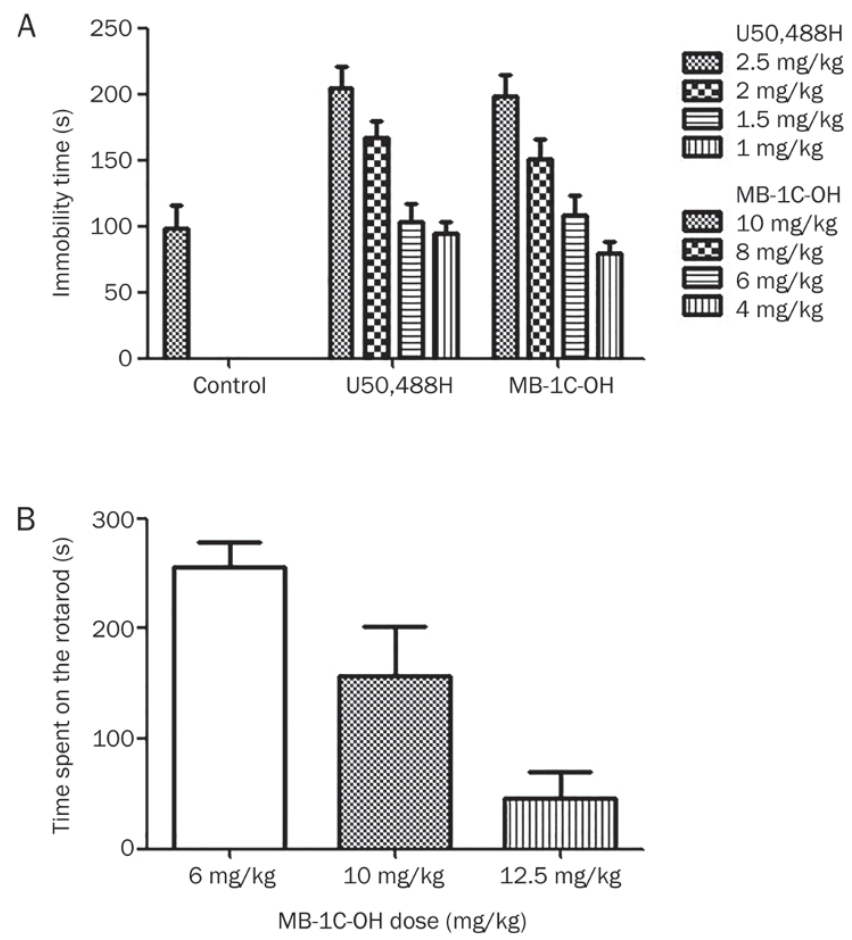

Figure 4. The depressive effect of $\mathrm{MB}-1 \mathrm{C}-\mathrm{OH}$ in the forced swimming test and the sedative effect of $\mathrm{MB}-1 \mathrm{C}-\mathrm{OH}$ in the rotarod test. (A) Mice were administered (sc) saline, (-) U50,488H or MB-1C-OH. After $15 \mathrm{~min}$, they were put singly into transparent Plexiglas cylinders containing water at a depth of $10 \mathrm{~cm}$ for $6 \mathrm{~min}$. The immobility time was recorded during the final $4 \mathrm{~min}$. Data for each group are presented as the mean \pm SEM from 5-12 animals. (B) Mice were subcutaneously administered various doses of MB-1C-OH. Then, 15 min later, mice were put singly on a rotarod for $300 \mathrm{~s}$. The duration time before each mouse fell off the rotarod was recorded. Data for each group are presented as the mean \pm SEM from 10 animals.

\section{Discussion}

The present study demonstrated that $\mathrm{MB}-1 \mathrm{C}-\mathrm{OH}$ had high affinity for the K-opioid receptor with a $K_{\mathrm{i}}$ value of $35 \mathrm{nmol} / \mathrm{L}$ in the receptor binding assay. With the $\left.{ }^{35} \mathrm{~S}\right] \mathrm{GTP} \mathrm{S}$ binding assay, a classical functional measurement for receptor activation that can be used to determine the potencies and efficacies of opioid ligands at opioid receptors ${ }^{[25]}$, we found that MB- 
Table 4. Depression effects in mouse forced swimming test and sedation effects in mouse rotarod test.

\begin{tabular}{lcccc}
\hline Compounds & $\begin{array}{c}\text { Depression } \mathrm{ED}_{50} \\
(\mathrm{mg} / \mathrm{kg}, \mathrm{sc})\end{array}$ & $\begin{array}{c}\text { Depression } \mathrm{ED}_{50} / \\
\text { antinociceptive } \mathrm{ED}_{50}\end{array}$ & $\begin{array}{c}\text { Sedation } \mathrm{ED}_{50} \\
(\mathrm{mg} / \mathrm{kg}, \mathrm{sc})\end{array}$ & $\begin{array}{c}\text { Sedation } \mathrm{ED}_{50} / \\
\text { antinociceptive } \mathrm{ED}_{50}\end{array}$ \\
\hline $\mathrm{MB}-1 \mathrm{C}-\mathrm{OH}$ & $9.49(8.84-10.18)$ & 24.33 & $9.29(8.75-9.87)$ & 23.82 \\
$(-) \mathrm{U} 50,488 \mathrm{H}$ & $2.35(2.21-2.50)$ & 2.64 & $3.32(2.65-3.94)^{\mathrm{a}}$ & 3.73 \\
\hline
\end{tabular}

${ }^{a}$ The sedation $\mathrm{ED}_{50}$ of $(-) \mathrm{U} 50,488 \mathrm{H}$ were cited from our precious data ${ }^{[17]}$.

$\mathrm{ED}_{50}$ values of maximal possible effect (\% MPE) obtained from mice acetic acid writhing test (in parentheses are $95 \%$ confidence limits).

1C-OH stimulated $\left[{ }^{35} \mathrm{~S}\right] \mathrm{GTP} \gamma \mathrm{S}$ binding to membrane receptors with an $E_{\max }$ of $98 \%$ and an $\mathrm{EC}_{50}$ value of $16.7 \mathrm{nmol} / \mathrm{L}$. These results indicate that $\mathrm{MB}-1 \mathrm{C}-\mathrm{OH}$ is a highly selective, potent K-opioid receptor agonist.

It have been well demonstrated that $\mathrm{K}$-agonists produce potent antinociception in different animal pain models ${ }^{[9,11-13]}$. Our findings were similar to these studies in that we found that $\mathrm{MB}-1 \mathrm{C}-\mathrm{OH}$ produced a significant antinociceptive effect in the acetic acid-induced writhing test via $\mathrm{K}$ - but not $\mu$ - or $\delta$-opioid receptors. Furthermore, compared with morphine and (-)U50,488H, MB-1C-OH displayed more potent antinociception in the acetic acid-induced writhing test. In the formalin test, MB-1C-OH also significantly inhibited formalininduced flinching behavior in the second phase. These results suggested that MB-1C-OH, a full $\mathrm{k}$-receptor agonist, produced potent antinociceptive effects and were similar to our previous findings ${ }^{[4,7,16]}$.

More importantly, we found that MB-1C-OH had no effects on the mouse hot plate and tail flick tests. Because the hot plate and tail flick tests both measure responses to thermal pain and often reflect central drug actions mediated by supraspinal and spinal mechanisms ${ }^{[26,27]}$, our results suggested that the antinociceptive effects of $\mathrm{MB}-1 \mathrm{C}-\mathrm{OH}$ may occur via a peripheral- rather than a central-acting mechanism. We further evaluated the antinociception produced by $\mathrm{MB}-1 \mathrm{C}-\mathrm{OH}$ using the acetic acid-induced writhing and formalin tests. These tests are both widely used to measure analgesic activity ${ }^{[28-30]}$. The formalin test occurs in two phases. The first phase is characterized by neurogenic pain caused by the direct chemical stimulation of nociceptors. The second phase is characterized by inflammatory pain triggered by a combination of stimuli $^{[31,32]}$. Drugs that act primarily on the central nervous system inhibit both phases equally, whereas peripherally acting drugs only inhibit the late phase ${ }^{[33]}$. MB-1C-OH produced significant inhibition of flinching behavior in the second phase but not in the first phase, suggesting that its antinociceptive effect may be related to peripheral action on inflammatory pain. The precise mechanisms of MB-1C-OH-induced antinociception are of great interest and need to be elucidated in future studies. Many recent studies have shown that $\mathrm{K}$-opioid agonists produced analgesic effect via peripheral $\mathrm{K}$-opioid receptor ${ }^{[9-13]}$ without producing undesirable side effects.

Activation of the $\mathrm{K}$-receptor produces severe, undesirable central nervous system side effects, which limit the clinical utility of $\mathrm{k}$-receptor agonists for pain relief ${ }^{[34,35]}$. In the present study, we found that the depression and sedation $\mathrm{ED}_{50}$ values of $\mathrm{MB}-1 \mathrm{C}-\mathrm{OH}$ are much higher than the $\mathrm{ED}_{50}$ value for antinociception. In contrast, the doses of (-) U50,488H that produce depression and sedation were similar to those that produce antinociception. These results demonstrated that $\mathrm{MB}-1 \mathrm{C}-\mathrm{OH}$ produced less risk for sedation and depression than the classical k-agonist (-)U50,488H.

In summary, MB-1C-OH, a novel selective $\mathrm{\kappa}$-opioid receptor agonist, produced potent antinociceptive effects and little sedation and depression. Taken together, MB-1C-OH may be a promising analgesic for pain relief.

\section{Acknowledgements}

This research was supported by grants from the National Basic Research Program: a grant from the Ministry of Science and Technology of China 2009CB522005 (Jing-gen LIU) and grants from National Natural Science Foundation of China 81130087 (Jing-gen LIU) and 81171296 (Xiao-wu HU).

\section{Author contribution}

Jing-gen LIU, Yu-jun WANG, and Tao XI designed and supervised the research project; Yun-gen XU provided the compound; Le-sha ZHANG, Jun WANG, Yi-min TAO, Yuhua WANG, Xue-jun XU, Jian-chun CHEN, Xiao-wu HU and Jie CHEN performed the experiments; Le-sha ZHANG, Jun WANG, and Yu-jun WANG analyzed the data and wrote the manuscript; Yu-jun WANG revised the manuscript.

\section{References}

1 Trescot AM, Datta S, Lee M, Hansen H. Opioid pharmacology. Pain Physician 2008; 11: S133-53.

2 Ballantyne JC. Opioid analgesia: perspectives on right use and utility. Pain Physician 2007; 10: 479-91.

3 Clark JA, Pasternak GW. U50,488: a kappa-selective agent with poor affinity for mu1 opiate binding sites. Neuropharmacology 1988; 27 : 331-2.

4 Sun JF, Wang YH, Li FY, Lu G, Tao YM, Cheng Y, et al. Effects of ATPM$\mathrm{ET}$, a novel $\mathrm{K}$ agonist with partial $\mu$ activity, on physical dependence and behavior sensitization in mice. Acta Pharmacol Sin 2010; 31: 1547-52.

5 Wang YH, Sun JF, Tao YM, Chi ZQ, Liu JG. The role of kappa-opioid receptor activation in mediating antinociception and addiction. Acta Pharmacol Sin 2010; 31: 1065-70.

6 Endoh T, Matsuura H, Tajima A, Izumimoto N, Tajima C, Suzuki T, et al. Potent antinociceptive effects of TRK-820, a novel kappa-opioid receptor agonist. Life Sci 1999; 65: 1685-94. 
7 Tao YM, Li QL, Zhang CF, Xu XJ, Chen J, Ju YW, et al. LPK-26, a novel kappa-opioid receptor agonist with potent antinociceptive effects and low dependence potential. Eur J Pharmacol 2008; 584: 306-11.

8 Negus SS, Mello NK, Portoghese PS, Lin CE. Effects of kappa opioids on cocaine self-administration by rhesus monkeys. J Pharmacol Exp Ther 1997; 282: 44-55.

9 Riviere PJ. Peripheral kappa-opioid agonists for visceral pain. $\mathrm{Br} J$ Pharmacol 2004; 141: 1331-4.

10 Stein C, Lang $\sqcup$. Peripheral mechanisms of opioid analgesia. Curr Opin Pharmacol 2009; 9: 3-8.

11 Binder W, Machelska H, Mousa S, Schmitt T, Riviere PJ, Junien JL, et al. Analgesic and antiinflammatory effects of two novel kappa-opioid peptides. Anesthesiology 2001; 94: 1034-44.

12 Jolivalt CG, Jiang Y, Freshwater JD, Bartoszyk GD, Calcutt NA. Dynorphin A. kappa opioid receptors and the antinociceptive efficacy of asimadoline in streptozotocin-induced diabetic rats. Diabetologia 2006; 49: 2775-85.

13 Ko MC, Tuchman JE, Johnson MD, Wiesenauer K, Woods JH. Local administration of mu or kappa opioid agonists attenuates capsaicininduced thermal hyperalgesia via peripheral opioid receptors in rats. Psychopharmacology (Berl) 2000; 148: 180-5.

14 Liu JG, Prather PL. Chronic exposure to mu-opioid agonists produces constitutive activation of mu-opioid receptors in direct proportion to the efficacy of the agonist used for pretreatment. Mol Pharmacol 2001; 60: 53-62.

15 Wen Q, Yu G, Li YL, Yan LD, Gong ZH. Pharmacological mechanisms underlying the antinociceptive and tolerance effects of the 6,14-bridged oripavine compound 030418. Acta Pharmacol Sin 2011; 32: 1215-24.

16 Portoghese AS, Lipkowski AW, Takemori AE. Bimorphinans as highly selective, potent kappa opioid receptor antagonists. J Med Chem 1987; 30: 238-9.

17 Wang YJ, Tao YM, Li FY, Wang YH, Xu XJ, Chen J, et al. Pharmacological characterization of ATPM [(-)-3-aminothiazolo[5,4-b]- $\mathrm{N}$-cyclopropylmethylmorphinan hydrochloride], a novel mixed k-agonist and $\mu$-agonist/-antagonist that attenuates morphine antinociceptive tolerance and heroin self-administration behavior. J Pharmacol Exp Ther 2009; 329: 306-13.

18 Jiang Q, Heyman JS, Porreca F. Mu antagonist and kappa agonist properties of b-funaltrexamine (b-FNA): long lasting spinal antinociception. NIDA Res Monogr 1989; 95: 199-205.

19 Vanderah TW, Schteingart CD, Trojnar J, Junien JL, Lai J, Riviere PJ. FE200041 (D-Phe-D-Phe-D-Nle-D-Arg-NH2): A peripheral efficacious kappa opioid agonist with unprecedented selectivity. J Pharmacol Exp Ther 2004; 310: 326-33.

20 Saitoh A, Yoshikawa Y, Onodera K, Kamei J. Role of delta-opioid receptor subtypes in anxiety-related behaviors in the elevated plus- maze in rats. Psychopharmacology (Berl) 2005; 182: 327-34.

21 Hunskaar S, Hole K. The formalin test in mice: dissociation between inflammatory and non-inflammatory pain. Pain 1987; 30: 103-14.

22 David DJ, Renard CE, Jolliet P, Hascoet M, Bourin M. Antidepressantlike effects in various mice strains in the forced swimming test. Psychopharmacology (Berl) 2003; 166: 373-82.

23 Litchfield JT Jr, Wilcoxon F. A simplified method of evaluating doseeffect experiments. J Pharmacol Exp Ther 1949; 96: 99-113.

24 Shiotsuki H, Yoshimi K, Shimo Y, Funayama M, Takamatsu Y, Ikeda K, et al. A rotarod test for evaluation of motor skill learning. J Neurosci Methods 2010; 189: 180-5.

25 Zhu J, Luo LY, Li JG, Chen C, Liu-Chen LY. Activation of the cloned human kappa opioid receptor by agonists enhances $\left[{ }^{35} \mathrm{~S}\right] \mathrm{GTPgammaS}$ binding to membranes: determination of potencies and efficacies of ligands. J Pharmacol Exp Ther 1997; 282: 676-84.

26 Nemirovsky A, Chen L, Zelman V, Jurna I. The antinociceptive effect of the combination of spinal morphine with systemic morphine or buprenorphine. Anesth Analg 2001; 93: 197-203.

27 Rani S, Gupta MC. Evaluation and comparison of antinociceptive activity of aspartame with sucrose. Pharmacol Rep 2012; 64: 293-8.

28 Matsumoto A, Anan H, Maeda K. An immunohistochemical study of the behavior of cells expressing interleukin-1 alpha and interleukin-1 beta within experimentally induced periapical lesions in rats. J Endod 1998; 24: 811-6.

29 Vanderlei ES, Patoilo KK, Lima NA, Lima AP, Rodrigues JA, Silva LM, et al. Antinociceptive and anti-inflammatory activities of lectin from the marine green alga Caulerpa cupressoides. Int Immunopharmacol 2010; 10: 1113-8.

30 Shields SD, Cavanaugh DJ, Lee H, Anderson DJ, Basbaum Al. Pain behavior in the formalin test persists after ablation of the great majority of C-fiber nociceptors. Pain 2010; 151: 422-9.

31 Tjølsen A, Berge OG, Hunskaar S, Rosland JH, Hole K. The formalin test: an evaluation of the method. Pain 1992; 51: 5-17.

32 Puig S, Sorkin LS. Formalin-evoked activity in identified primary afferent fibers: systemic lidocaine suppresses phase- 2 activity. Pain 1996; 64: 345-55.

33 Bitencourt Fda S, Figueiredo JG, Mota MR, Bezerra CC, Silvestre PP, Vale MR, Nascimento KS, et al. Antinociceptive and anti-inflammatory effects of a mucin-binding agglutinin isolated from the red marine alga Hypnea cervicornis. Naunyn Schmiedebergs Arch Pharmacol 2008; 377: 139-48.

34 Wadenberg ML. A review of the properties of spiradoline: a potent and selective kappa-opioid receptor agonist. CNS Drug Rev 2003; 9: 187-98.

35 Dortch-Carnes J, Potter DE. Bremazocine: a kappa-opioid agonist with potent analgesic and other pharmacologic properties. CNS Drug Rev 2005; 11: 195-212. 